\title{
Evaluating Feasibility and Effectiveness of Digital Game-Based Instructional Technology
}

\author{
https://doi.org/10.3991/ijet.v16i16.23829 \\ Nguyen Thi Huong Giang $(\bowtie)$, Le Huy Cuong \\ Hanoi University of Science and Technology (HUST), Hanoi, Vietnam \\ giang.nguyenthihuong@hust.edu.vn
}

\begin{abstract}
Higher education institutions encounter difficulties when the Covid-19 pandemic happens because learners cannot go to class and absorb knowledge directly. In Vietnam, universities have used online learning to help learners keep learning in this pandemic context. However, students and teaching staff have expressed concerns about the quality of the learning process. In this context, our research is looking for solutions to apply new technology in the teaching process to ensure the quality and effectiveness of learning. Among these new technologies, we consider digital games because most students play digital games and their positive effects on teaching, as evidenced by recent publications. Under the approach of technological process, our team evaluated the feasibility and effectiveness of the digital game-based instructional technology at HUST. In terms of feasibility, research shows that most students agree that digital games can contribute to learning skills. In terms of effectiveness, there are three key findings. First, although male students play video games more than female students, the results show that both men and women have the same rate of digital games' effectiveness in learning. Second, there is no difference in assessing the effectiveness of digital games in learning between IT students and non-IT students although IT students are more exposed to technology. Third, there is a difference in the views of second-year students and third-year students. This difference illustrates the need for blended-learning courses that utilize digital games effectively for third-year engineering students who start more specialized engineering courses at universities.
\end{abstract}

Keywords — digital game-based learning, instructional technology, learning skill

\section{Introduction}

The Covid-19 pandemic had a strong impact on the teaching process, creating an inevitable trend of digital transformation in teaching and learning process. In $\mathrm{Vi}$ etnam, during the complicated Covid-19 epidemic, there were nearly $80 \%$ of students studying online, ranking 17 th among 200 countries and territories. With the advantage of a country with a large proportion of people owning and using technology, being in the top 20 countries with the highest number of Internet users in the world, 49 million people connected to the Internet, $55 \%$ of Vietnamese people owning smartphones and 
$46 \%$ owning personal computers, Vietnam is considered a bright spot for students to easily access technology in education [1]. In this process of bringing digital technology into teaching, digital game-based learning is a method that creates a lot of excitement for learners but also requires creativity of the teachers. Therefore, it is necessary to produce in-depth studies on the feasibility and effectiveness to deploy teaching using digital games, especially in higher education, Vietnam.

In higher education, students are adults and they have equipped themselves with high school learning experiences and skills. In addition, they have the habit of using technology in learning and relaxing, especially playing video games. According to the survey results of online game services in Vietnam in the context of international integration of the Institute of Sociology proposed by the National Assembly's Committee for Culture, Education, Youth, Adolescents and Children, game players are mostly children under 20 years old, accounting for $68.4 \%$, and $42.1 \%$ are children in the $16-$ 20 group and more than $26 \%$ in the group from 10 to 15 years. The proportion of game players who are attending school accounts for two thirds (71.7\%) and the majority are pupils and students. Researchers at the Institute of Sociology also asked [2]: How can video games be valuable and effective? $71.5 \%$ of respondents think that video games should be composed with attractive and educational scripts. $67.2 \%$ suggest classifying video games according to age groups. $65 \%$ encourage video games with healthy contents to educate about national cultural traditions and history. $51.6 \%$ support controlling internet use for children under 14 years old. 50.4\% recommend more strongly the negative side of video games. We think it is an excellent advantage for universities in Vietnam to utilize digital games in their teaching. We take this opportunity to survey students from Hanoi University of Science and Technology (HUST) to determine how well they could form learning skills from various digital games, including adventure, multi-level, puzzle, role-playing, shooting, sports and strategy games. The learning skills that could be formed by playing digital games include Recalling facts, Critical thinking, Problem-solving, Planning and strategy, Cooperation and teamwork, Decision making, Negotiation, System management, Hand and eye coordination (Ingenuity practice). Furthermore, the research team also asked the students how much they improved their learning efficiency, whether learning would become more straightforward, and students would have the opportunity to apply knowledge into real life or experience practical situations and improve learning outcomes for learners when using digital games in the teaching process. These research results show positive signals about the feasibility of developing learning skills and the effectiveness of applying digital games into higher education from the learners' points of view.

The next part of the paper will introduce the concept of digital games and digital game-based learning, the approach of digital game-based instructional technology and general evaluation of research on effectiveness of game-based learning gained so far. The article also describes the research process conducted at HUST on digital gamebased instructional technology on both feasible and effective aspects; and discusses the current situation and recommendations for the effective implementation of digital game-based learning in higher education. Specific structures of this paper include: 
- Literature review of digital game-based learning.

- Design research for survey on the feasibility and effectiveness of digital gamebased instructional technology.

- Population and sample for survey.

- Data collection tools and methods.

- Description of data.

- Survey results achieved.

- Discussion and recommendations.

\section{$2 \quad$ Literature review}

\subsection{Definition of digital games and digital game-based learning}

Serious games have been used for physics education since the early 1980s ([3], [4]). With the proliferation and availability of technology devices, digital games have become more widely used than traditional games. Referring to the concept of a digital game, Prensky (2001) described six structural elements of the game: rules, goals, results and feedback, competition or challenge, interaction and representation, or story [5]. Dempsey et al (2002) defined: "A game is an activity involving one or more players, with objectives, constraints, rewards and outcomes, guided by rules, artificially in some aspects and there is an element of competition" [6].

In 2005, a serious game was defined by Zyda as "a mental contest, played against the computer according to specific rules, using entertainment for further training to the government, or corporate, education, health, public policy and strategic communication goals." [7] Unlike an entertaining game, a serious game is designed for educational rather than entertainment purposes [8]. Serious games are considered as entertainment tools for educational purposes, where players sharpen their knowledge and skills by overcoming many obstacles during the game. The player's performance is scored over the course of the game [9]. In case the player gets over an obstacle, he will receive several rewards such as score, promotion and strength. Educational elements can be integrated into the game, which the player will subconsciously absorb during the game. Extending the definition of digital games used in teaching, De Freitas (2006) defined: "Applications use the features of computer and video games to create attractive and engaging learning experiences to gain specific learning goals, outcomes and experiences" [10].

Alternate Reality Game (ARG) is a game that requires participation in the real world (McGonigal, 2011 [11]). Unlike most other game genres, ARG uses real-world media to provide its composition. Media include text messaging, email, social networking services and websites (Gilliam et al., 2017 [12]). Barlow argues that ARG is a game in which gamers can play in both real and online virtual worlds under the assumption that a virtual event occurs in the real world [13]. Awareness of some of the basic concepts associated with ARG, such as puppet masters, veils and predecessors, will help to better understand ARG (Dominik, 2008 [14]; Olbrish, 2011 [15]). 
Gamification is the alteration of something that is not a game through a game or the use of game elements (van Grove, 2011 [16]; Werbach \& Hunter, 2012 [17]). Gamification can be a means of engaging employees on tasks (Reeves \& Read, 2009 [18]), fostering collaboration (McGonigal, 2011 [19]) or improving motivation (Zichermann \& Linder, 2013 [20]). Deterding, Dixon, Khaled, and Nacke defined "gamification" as "the use of game design elements in a non-game context" [21]. In other words, gamification is a set of activities and processes to solve problems by using or applying the characteristics of game elements.

According to Alsubhi et al. (2020), today's university students use e-learning resources to access information and perform general questions solving learning problems. Such online environments offer alternatives to the traditional way of learning, currently considered expensive and time-consuming with mixed results. Students' online dropout is believed to have stemmed from the e-learning foundations of university education. Therefore, e-learning developers use Gamification to minimize this limitation of e-learning. [22]

Through the different definitions above, we can see that digital games in teaching have such roles as a positive learning environment, motivational tools, as a playground and as an instructional and discovered technology designed by educators for learning purposes (Nicola Whitton (2014), [in 23]). To apply effectively in teaching, the field of digital game-based learning needs to be evaluated from a multidisciplinary point of view, considering research from different fields such as computer science, psychology, and education, neuroscience and game design. In the perspective of the authors, we would like to evaluate digital game-based learning according to the technology approach.

\subsection{Digital game-based learning as a technological process}

The influence of technology is becoming more and more common in the academic process at the university level, all learners adapt to the way they interact with computers and we cannot make broad assumptions about a specific generation or any group of learners. Instead, we should cater to all levels of technical competence and accept that many learners (of all ages) simply enjoy communicating, playing, and learning in ways not relating to technology. Digital game-based learning is not a simple solution but will revolutionize teaching and learning in higher education by attracting a new 'generation' of learners depending on the circumstances. It is important to view digital games as tools and simple means available to lecturers. When reviewed and implemented in relation to the limitations of the educational system and appropriate pedagogical models, they can provide an attractive way of learning. To deploy digital game-based learning, according to the approach of instructional technology, each plan of instructional design will be a combination of means, methods and skills. This combination is how to create the teaching games satisfying certain learning goals (such as the formation of learning skills at different levels), therefore whole instructional technology for how to make teaching game in the certain learning circumstance is known as the possible option. All possible options for making digital game-based learning to meet the teaching effectiveness criteria such as How suitable is it? Is it easy to learn?; 
How is the level of access to knowledge and experience? that is called an efficient option (low to high) [24]. Thus, the digital game-based learning instructional technology is a system of teaching means, teaching methods and teaching skills for teaching using digital games to apply many objective laws such as cognitive neuroscience, psychology and pedagogy influencing learner to create his/her definite personality. [25] So digital game-based learning can be called by digital game-based instructional technology.

Each teaching plan combines teaching means, teaching methods and teaching skills to create a corresponding technological achievement. Depending on the specific effectiveness criteria (quantity or quality) set out before the implementation of the technology, this will be acceptable or not. Thus, feasibility and efficiency are two typical properties, expressing the meaning of a technology solution, which is a reliable basis for choosing the solution of digital game-based learning. From a feasible perspective, to identify the solution using digital game-based learning in the usable range, our research considers the formation of learning skills through the use of typical digital games in learning. From an efficiency perspective, it is necessary to consider all possible options that meet the efficiency criteria set from low to high. Therefore, to build these effective criteria, we will re-evaluate international studies on effectiveness of teaching using digital games, and then select typical efficiency criteria, build a set of criteria to evaluate the effectiveness of teaching plans using digital games.

\subsection{The efficiency criteria of digital game-based instructional technology}

According to Marc Prensky, neuroscientists C. Shawn Green and Daphne Bavelier of the University of Rochester have had studies showing that playing "action" videos and computer games have a positive effect on increasing students' attention. However, that finding is only a small part of the more important message that all parents and educators need to understand: Video games are not enemies, but good opportunities which can be created for learners to engage in real learning if used correctly. [in 5]

Another prominent researcher, James Paul Gee (2003), focuses on principles of video game-assisted learning and how these principles can be applied in the classroom. Video games can be used as a tool to challenge players while learning. They motivate players to persevere and at the same time teach players how to play. These games provide an overview of new ways for learning in school, community and at work. [26]

Authors - both experienced educators and gamers - assume that 21 st century students learn differently from previous generations. By incorporating digital games into the lessons, students' learning experience can be more realistic, more attractive and better prepared for apprenticeship. [27]

In recent years, the use of games has proven to be successful in encouraging learners' participation and sustaining learners' contribution. The developments in video games, serious computer games and game-based learning are becoming important to virtual learning environments [in 28]. Early exposure to technology has changed the way in which young people think and use technology. Prensky (2001) describes a clear distinction between 'digital natives', a term commonly used to describe people 
born and living in the digital age, with other names such as Generation Z, Generation Alpha ... they are the ones who grew up with computer games, television and other media, and used them to instinctively learn and older learners, whose collaboration with these types of technologies must be done through conscious effort. He argued that the generation of adults raised in the computer world (most of the current student generation) was cognitively different from previous generations, and that immersion in technology fundamentally changed the way that people obtain and assimilate information.

Digital games can provide a virtual environment where students are not limited by physical space or have direct access to material (Busch, Conrad, \& Steinickie, 2013) [29]. Participation in Digital Games allows for active accumulation of knowledge. Complex situations in digital games create opportunities for users to take on roles and participate in critical thinking activities (Sardone \& Devlin-Scherer, 2010) [30]. Digital games can have a positive impact on a user's understanding of real-world situations (Ibrahim, 2010), and immediate digital feedback can allow for in-depth processing of embedded content [31]. Digital games are an effective and motivating approach to encourage students to create knowledge (Papastergiou, 2009) [32]. Digital games can significantly improve knowledge about embedded topics and increase students' interest and motivation for the content (Papastergiou, 2009). Students, both boys and girls, are equally motivated to participate in digital games (Papastergiou, 2009).

Studies in the world have confirmed many advantages when implementing digital game-based learning, but according to qualitative research in Cavus's Web of Science database, the application of games alone in developing strategy management skills, namely Business Strategy Games (BSG) and Learning Strategy Management still shows many limitations, so it is affirmed that there is a need to do more research on deploying business strategy game and learning strategy management [33].

A study in Vietnam on digital game-based learning has mentioned the level of development and attitudes about this issue. Huyen, P.T.T have affirmed, gamification has begun to play a certain role in learning English both inside and outside the classroom in the context of the author's research. Students are technologically wellprepared for online games and maintain a positive attitude toward game learning. However, online games are mainly used to aid vocabulary learning [34].

Other studies have also given some criteria as a measure of the quality of digital game-based learning (perception, technology application, attitudes, personal characteristics...). In Baig's (2020) study, results indicate that video games based on the Math curriculum have a positive impact on student performance based on their average scores in standard tests, when compared with traditional learning methods [35]. Also applied to math teaching, it is confirmed by Wahidah et al. that using digital games to design multimedia confirmed not only helps learners remember and read, but also helps learners participate in the process of finding concepts. The learning process is fun and interactive [36]. An area related to language teaching has also produced positive results using digital games, such as research report of Backman et al., based on computer game technology as well as in dialogue education theory and debate theory, the effectiveness of dialogue interventions to develop communication for 
people with aphasia has been improved [37]. In Yamani's methodological research, in-depth discussion on the differences between Digital Games, game-based learning and games was discussed. The findings suggest a conceptual framework for integrating gamification in eLearning systems based on the Instructional Design Model. Gamification has been incorporated into the general phases of the instructional design model, which are analysis, design, development, implementation, and evaluation. The findings help decision-makers and stakeholders in higher education institutions differentiate between games, game-based learning, and integrate gamification into education, and identify appropriate instrutional design models as conceptual frameworks to systematically deliver learning content through gamification [38].

In short, the effective criteria for teaching using digital games mentioned by international publications revolve around the following basic contents:

- Digital game-based learning is an appropriate teaching method.

- Digital game-based learning makes the learning process easy and interesting.

- Digital game-based learning helps learners apply knowledge learned in games into real life.

- Digital game-based learning can be used to improve learning outcomes.

- Digital game-based learning helps students learn through practical situations simulated in a game.

Based on these conclusions, our research will propose survey criteria in research design to evaluate the feasibility and effectiveness of digital game-based instructional technology.

\section{$3 \quad$ Methods and results}

\subsection{Research design}

Stemming from the characteristics of Vietnamese young people, especially students, who are very connoisseurs of technology and most of them experience digital games as analyzed above, the respondents of the article will be students who are studying at HUST. Therefore, within the scope of the paper, our research shows students' perceptions of the feasibility of developing learning skills from the seven popular types of digital games and to evaluate the impact of digital games on the learning process of students at HUST.

Based on the research objective of the feasibility and effectiveness of digital gamebased instructional technology at higher education institutions (section 2.2), based on the effects brought about by digital game-based instructional technology through different research projects in the world in section 2.3, the authors built 15 survey criteria divided into 2 groups as follows:

Criterion group 1 (feasibility): Learning skills can be formed when participating in digital games (see Table 1).

Criterion group 2 (effectiveness): The level of effectiveness of a digital game on the learning process (see Table 2). 
Table 1. Learning skills

\begin{tabular}{|l|l|c|l|l|}
\hline Item\# & \multicolumn{1}{|c|}{ Types of learning skills } & Item\# & Types of learning skills \\
\hline F1. & Facts recalling & F6. & Decision making skills \\
\hline F2. & Thought and thinking practice & F7. & Negotiation skills \\
\hline F3. & Problem solving skills & F8. & System management skills \\
\hline F4. & Planning and strategy planning & & F9. & Hand and eye coordination \\
\hline F5. & Cooperation and teamwork skills & & F10. & Ingenuity practice \\
\hline
\end{tabular}

Table 2. Effects of digital game in learning process

\begin{tabular}{|l|l|}
\hline \multicolumn{1}{|c|}{ Item\# } & \multicolumn{1}{c|}{ Effectiveness of teaching using digital games } \\
\hline E1. & An appropriate teaching method in higher education \\
\hline E2. & Makes the learning process easy and interesting \\
\hline E3. & Helps students apply knowledge learned in games into real life \\
\hline E4. & Can be used to improve student learning outcomes \\
\hline E5. & Helps students learn through practical situations simulated in a game \\
\hline
\end{tabular}

Therefore, the model of digital game-based instructional technology is designed according to feasibility and effectiveness that was described as seen in Fig.1.

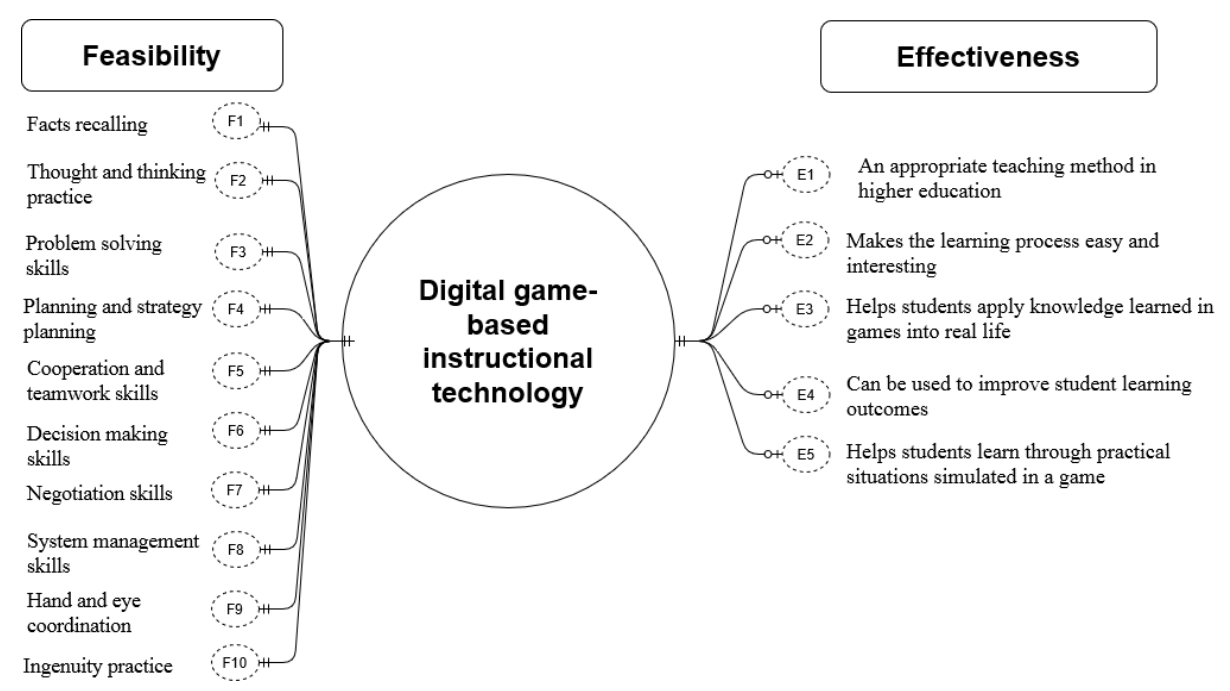

Fig. 1. Evaluation model of digital game-based instructional technology

\subsection{The population and sampling of survey}

The survey was conducted on students of HUST in the first semester of the 20202021 school year with a total population of about 35,000 students.

Survey sampling was selected based on three parameters according to the Yamane formula (1967) in [39]. 
The level of precision, sometimes called sampling error (e): is the range in which the true value of the population is estimated to be.

The Confidence level or risk level is the true population value within the range of precision specified earlier.

The degree of variability ( $p$ ) in the attributes being measured to the distribution of attributes in the population. The less variable (more homogeneous) a population, the smaller the sample size and vice versa.

Table 3. Sample size for $\pm 3 \%, \pm 5 \%, \pm 7 \%$ and $\pm 10 \%$ Precision Levels Where Confidence Level is $95 \%$ and $\mathrm{P}=0.5$

\begin{tabular}{|l|c|c|c|c|}
\hline \multirow{2}{*}{ Size of Population } & \multicolumn{4}{|c|}{ Sample Size (n) for Precision (e) of } \\
\cline { 2 - 5 } & $\mathbf{\pm 3 \%}$ & $\mathbf{\pm 5 \%}$ & $\mathbf{\pm 7 \%}$ & $\mathbf{\pm 1 0 \%}$ \\
\hline 15,000 & 1,034 & 390 & 201 & 99 \\
\hline 20,000 & 1,053 & 392 & 204 & 100 \\
\hline 25,000 & 1,064 & 394 & 204 & 100 \\
\hline 50,000 & 1,087 & 397 & 204 & 100 \\
\hline 100,000 & 1.099 & 398 & 204 & 100 \\
\hline$>100,000$ & 1,111 & 400 & 204 & 100 \\
\hline
\end{tabular}

From the Yamane formula (1967)

With size of population is approximately 35.000, the level of precision (e) of $\pm 7 \%$ where confidence level $95 \%$ and the degree of variability $\mathrm{P}=0.5$, look up the table 1 , the minimum of sample size is 204. In this survey, we have received 206 records from 206 students participating in the survey, ensuring the level of precision (e) of $\pm 7 \%$ where confidence level $95 \%$ and the degree of variability $\mathrm{P}=0.5$.

\subsection{Data collection}

The survey research method based on the questionnaire survey is mainly used in the study. We use questionnaires containing 15 criteria in 2 groups of feasibility and effectiveness proposed in section 3.1 to systematically collect research-related data from students of HUST. The questionnaires are designed on Google Forms and data collection is organized online. The link of the questionnaire is: https://forms.gle /zPkmV978hKWJMAcr9

\subsection{Data description tool}

The process of data description in research uses univariate descriptive statistics such as frequency distribution to aggregate the frequency of individual values or the range of values of a research variable; arithmetic mean (Mean) to estimate the center when distributing values; standard deviation is one measure of dispersion or values positioned around central tendency through how close or distant each value is from the mean of the distribution.

In the survey of this study, questions containing scales are used. With the Likert 5level scale: (1) Totally disagree; (2) disagree; (3) Partially agree; (4) Absolutely 
agree; (5) Totally agree. In which, the Mean is the average value that has many meanings, namely the level 3 is the intermediate, if it is inclined to 3-5, it means that the respondents agree with the view of the variable given. Conversely, if it is biased to 13 , respondents disagree with the opinion of the variable. About Std. Deviation, smaller the standard deviation of the variable shows that the respondents answering the number of answers does not differ much. On the contrary, if this value is high, it shows that the respondents have many different views with that variable, so the difference is quite high.

In addition, the research also discusses the comparison of two groups through the ttest statistical test method. Does the T-test look at whether the mean values of the two groups are statistically different?

\subsection{Survey results}

Learning skills are formed through digital games. The survey results show that $64.29 \%$ of students' opinion agree that digital games can form thought and thinking practice skill (F2), accounting for the largest proportion. Next, ranked second is the hand-to-eye coordination skill (F9) with a 58.39\% agreement rate. Decision-making skill (F6) is ranked third with the student's consent rate of $58.32 \%$. Accounting approximately $50 \%$ of consent rate are problem-solving skills (F3, 55.34\%), planning and strategy planning skills (F4, 52.08\%), ingenuity practice skill (F10, 51.94\%). In contrast, the most difficult skill to be formed in teaching using digital games is negotiation (F7, only $21.78 \%$ of respondents agree), followed by system management skills (F8, the rate of agreement is only $27.46 . \%$ ) (see more in table 4)

Table 4. Hierarchy of types of learning skills formed through digital games

\begin{tabular}{|l|c|c|c|}
\hline No\# & Type of learning skills & Percentage (\%) & Order of choice \\
\hline 1 & F1 & 44.17 & 7 \\
\hline 2 & F2 & 64.29 & 1 \\
\hline 3 & F3 & 55.34 & 4 \\
\hline 4 & F4 & 52.08 & 5 \\
\hline 5 & F5 & 43.13 & 8 \\
\hline 6 & F6 & 58.32 & 3 \\
\hline 7 & F7 & 21.78 & 10 \\
\hline 8 & F8 & 27.46 & 2 \\
\hline 9 & F9 & 58.39 & 6 \\
\hline 10 & F10 & 51.94 & \\
\hline
\end{tabular}

Effectiveness of using digital games in learning process at HUST. The criteria on the table 5 with the mean value in the range of 4 show that the students participating in the survey agree, in other words, the students will enjoy this new teaching method $(E 2$, mean $=4.0728)$ and realize that this is a learning method that allows learners to experience a lot $(\mathrm{E} 5$, mean $=3.9320)$ as well as apply knowledge to solve practical situations $(\mathrm{E} 3$, Mean $=3.9078)$. 
Table 5. Mean values of criteria describing the effectiveness of digital game-based instructional technology

\begin{tabular}{|l|c|c|c|c|c|}
\hline \multicolumn{1}{|c|}{ Criteria } & N & Minimum & Maximum & Mean & Std. Deviation \\
\hline E1 & 206 & 1.00 & 5.00 & $\mathbf{3 . 7 9 1 3}$ & .92664 \\
\hline E2 & 206 & 1.00 & 5.00 & $\mathbf{4 . 0 7 2 8}$ & .88870 \\
\hline E3 & 206 & 1.00 & 5.00 & $\mathbf{3 . 9 0 7 8}$ & .90862 \\
\hline E4 & 206 & 1.00 & 5.00 & $\mathbf{3 . 6 6 0 2}$ & .96831 \\
\hline E5 & 206 & 1.00 & 5.00 & $\mathbf{3 . 9 3 2 0}$ & .91345 \\
\hline Valid N (listwise) & 206 & & & & \\
\hline
\end{tabular}

Compare the evaluation about the effectiveness of digital game-based instructional technology by gender. To comparing these evaluations by gender, the research uses the results of t-test in table 6 .

Table 6. Results of t-test comparing the effectiveness of digital game-based instructional technology by gender

\begin{tabular}{|l|c|c|c|c|c|}
\hline \multicolumn{1}{|c|}{ Criteria } & Gender & $\mathbf{N}$ & Mean & Std. Deviation & Std. Error Mean \\
\hline \multirow{2}{*}{ E1 } & Male & 153 & 3.7647 & .95810 & .07746 \\
\cline { 2 - 6 } & Female & 53 & 3.8679 & .83292 & .11441 \\
\hline \multirow{3}{*}{ E2 } & Male & 153 & 4.0065 & .93539 & .07562 \\
\cline { 2 - 6 } & Female & 53 & 4.2642 & .71120 & .09769 \\
& Male & 153 & 3.8693 & .95071 & .07686 \\
\cline { 2 - 6 } & Female & 53 & 4.0189 & .77187 & .10603 \\
\hline \multirow{2}{*}{ E5 } & Male & 153 & 3.6405 & .99746 & .08064 \\
\cline { 2 - 6 } & Female & 53 & 3.7170 & .88529 & .12160 \\
\hline
\end{tabular}

\begin{tabular}{|l|l|c|c|c|c|c|}
\hline Criteria & \multicolumn{5}{|c|}{ Independent Samples Test } \\
\hline \multirow{2}{*}{} & & $\begin{array}{c}\text { Levene's Test for Equality } \\
\text { of Variances }\end{array}$ & \multicolumn{2}{|c|}{ t-test for Equality of Means } \\
\hline \multirow{2}{*}{ E1 } & & F & Sig. & t & df & Sig. (2-tailed) \\
\hline \multirow{2}{*}{ E2 } & Equal variances assumed & 3.551 & 0.061 & -0.698 & 204 & 0.486 \\
\cline { 2 - 8 } & Equal variances not assumed & & & -0.747 & 103.177 & 0.457 \\
\hline \multirow{2}{*}{ E3 } & Equal variances assumed & 0.717 & 0.398 & -1.829 & 204 & 0.069 \\
\cline { 2 - 8 } & Equal variances not assumed & & & -2.085 & 118.441 & 0.039 \\
\hline \multirow{2}{*}{ E4 } & Equal variances assumed & 2.939 & 0.088 & -1.033 & 204 & 0.303 \\
\cline { 2 - 8 } & Equal variances not assumed & & & -1.142 & 110.568 & 0.256 \\
\cline { 2 - 7 } & Equal variances assumed & 0.593 & 0.442 & -0.494 & 204 & 0.621 \\
\hline \multirow{2}{*}{ E5 } & Equal variances not assumed & & & -0.524 & 101.101 & 0.601 \\
\cline { 2 - 7 } & Equal variances not assumed & & & -1.615 & 103.596 & 0.109 \\
\hline
\end{tabular}


In table 6, the values of Levene's Test for Equality of Variances have sig $>0.05$ and sig at t-test $>0.05$ (Equal variances assumed), so it should be concluded that there is no difference between the two groups of male and female students in terms of mean values describing the effects of digital games in studying at HUST.

Compare the evaluation about the effectiveness of digital game-based instructional technology by groups of discipline. The research team divided the number of students participating in the survey into two groups of disciplines: those not related to information technology (Non-IT) and groups related to information technology (IT).

Based on Levene's Test for Equality of Variances with sig $>0.05$ and sig at t-test> 0.05 (Equal variances assumed) (see in Table 7), we conclude that there is no difference in choice between two groups of disciplines, IT and non-IT.

Table 7. Results of t-test comparing the effectiveness of digital game-based instructional technology by groups of discipline

\begin{tabular}{|l|l|c|c|c|c|}
\hline \multirow{2}{*}{ Criteria } & Discipline & $\mathbf{N}$ & Mean & Std. Deviation & Std. Error Mean \\
E1 & Non-IT & 132 & 3.7652 & .98740 & .08594 \\
\cline { 2 - 6 } & IT & 74 & 3.8378 & .81134 & .09432 \\
\hline \multirow{2}{*}{ E2 } & Non-IT & 132 & 4.0606 & .90594 & .07885 \\
\cline { 2 - 6 } & IT & 74 & 4.0946 & .86276 & .10029 \\
\hline \multirow{2}{*}{ E3 } & Non-IT & 132 & 3.9091 & .92839 & .08081 \\
& IT & 74 & 3.9054 & .87849 & .10212 \\
\hline \multirow{2}{*}{ E4 } & Non-IT & 132 & 3.6288 & .94429 & .08219 \\
& IT & 74 & 3.7162 & 1.01388 & .11786 \\
\hline \multirow{2}{*}{ E5 } & Non-IT & 132 & 3.9091 & .97648 & .08499 \\
\cline { 2 - 6 } & IT & 74 & 3.9730 & .79335 & .09222 \\
\hline
\end{tabular}

\begin{tabular}{|c|c|c|c|c|c|c|}
\hline \multirow[b]{3}{*}{ Criteria } & \multicolumn{6}{|c|}{ Independent Samples Test } \\
\hline & & \multicolumn{2}{|c|}{\begin{tabular}{|c|} 
Levene's Test for \\
Equality of Variances
\end{tabular}} & \multicolumn{3}{|c|}{ t-test for Equality of Means } \\
\hline & & $\mathbf{F}$ & Sig. & $\mathbf{t}$ & df & Sig. (2-tailed) \\
\hline \multirow{2}{*}{ E1 } & Equal variances assumed & 6.626 & 0.011 & -0.539 & 204 & 0.59 \\
\hline & Equal variances not assumed & & & -0.57 & 176.677 & 0.57 \\
\hline \multirow{2}{*}{ E2 } & Equal variances assumed & 0.072 & 0.789 & -0.263 & 204 & 0.793 \\
\hline & Equal variances not assumed & & & -0.266 & 157.586 & 0.79 \\
\hline \multirow{2}{*}{ E3 } & Equal variances assumed & 0.127 & 0.722 & 0.028 & 204 & 0.978 \\
\hline & Equal variances not assumed & & & 0.028 & 158.42 & 0.977 \\
\hline \multirow{2}{*}{ E4 } & Equal variances assumed & 0.015 & 0.903 & -0.621 & 204 & 0.535 \\
\hline & Equal variances not assumed & & & -0.608 & 142.485 & 0.544 \\
\hline \multirow{2}{*}{ E5 } & Equal variances assumed & 4.215 & 0.041 & -0.481 & 204 & 0.631 \\
\hline & Equal variances not assumed & & & -0.509 & 178.075 & 0.611 \\
\hline
\end{tabular}

Compare the evaluation about the effectiveness of digital game-based instructional technology by groups of students in different courses. Surveying the differences between groups of students by course, the research found the difference be- 
tween the second and third year students in two criteria: (1) Teaching using digital games makes the learning process easy and interesting (E2) with Levene's Test for Equality of Variances with sig $=0.858>0.05$ and sig at $\mathrm{t}$-test $=0.014<0.05$ (Equal variances assumed) and (2) Teaching using digital games helps learners apply knowledge learned in games into real life (E3) with Levene's Test for Equality of Variances with sig $=0.949>0.05$ and sig at t-test $=0.044<0.05$ (Equal variances assumed) (see Table 8).

Table 8. Results of t-test comparing the effectiveness of digital game-based instructional technology by groups of students in different courses

\begin{tabular}{|c|c|c|c|c|c|}
\hline \multicolumn{2}{|c|}{ Course } & $\boldsymbol{N}$ & Mean & Std. Deviation & Std. Error Mean \\
\hline & Second year & 58 & 3.8793 & 1.01008 & .13263 \\
\hline \multirow{2}{*}{ E1 } & Third year & 88 & 3.6364 & .91201 & .09722 \\
\cline { 2 - 6 } & Second year & 58 & 4.2241 & .89918 & .11807 \\
\hline \multirow{2}{*}{ E2 } & Third year & 88 & 3.8523 & .87808 & .09360 \\
\cline { 2 - 6 } & Second year & 58 & 4.0862 & .86419 & .11347 \\
\hline \multirow{2}{*}{ E3 } & Third year & 88 & 3.7841 & .88990 & .09486 \\
\cline { 2 - 6 } & Second year & 58 & 3.5517 & .99424 & .13055 \\
\hline \multirow{2yyyyy}{*}{ E5 } & Third year & 88 & 3.6023 & .91651 & .09770 \\
\cline { 2 - 6 } & Second year & 58 & 3.9310 & 1.00633 & .13214 \\
\hline
\end{tabular}

\begin{tabular}{|l|l|c|c|c|c|c|}
\hline \multirow{4}{*}{ Criteria } & \multicolumn{7}{|c|}{ Independent Samples Test } \\
\cline { 2 - 8 } & & \multicolumn{1}{|c|}{$\begin{array}{c}\text { Levene's Test for } \\
\text { Equality of Variances }\end{array}$} & \multicolumn{2}{c|}{ t-test for Equality of Means } \\
\cline { 2 - 8 } & & F & Sig. & t & df & Sig. (2-tailed) \\
\hline \multirow{3}{*}{ E1 } & Equal variances assumed & 0.059 & 0.809 & 1.509 & 144 & 0.134 \\
\cline { 2 - 8 } & Equal variances not assumed & & & 1.477 & 113.283 & 0.142 \\
\hline \multirow{3}{*}{ E2 } & Equal variances assumed & 0.032 & 0.858 & 2.48 & 144 & 0.014 \\
\cline { 2 - 8 } & Equal variances not assumed & & & 2.468 & 120.088 & 0.015 \\
\hline \multirow{2}{*}{ E4 } & Equal variances assumed & 0.004 & 0.949 & 2.03 & 144 & 0.044 \\
\cline { 2 - 8 } & Equal variances not assumed & & & 2.043 & 124.631 & 0.043 \\
\hline \multirow{2}{*}{ E5 } & Equal variances assumed & 1.386 & 0.241 & -0.315 & 144 & 0.753 \\
\cline { 2 - 8 } & Equal variances not assumed & & & -0.31 & 115.078 & 0.757 \\
\hline & Equal variances assumed & 0.044 & 0.835 & 0.831 & 144 & 0.407 \\
\cline { 2 - 7 } & Equal variances not assumed & & & 0.819 & 115.91 & 0.415 \\
\hline
\end{tabular}

\section{Discussion and conclusion}

This study has evaluated the feasibility and effectiveness of teaching technology using digital games by consulting HUST's students in the common age of using technology and participating in digital games. In terms of feasibility, it is ensured that the successful implementation of digital game-based instructional technology. This feasibility is judged thanks to the learning skills which the games will help learners develop (which is the goal of teaching process). The efficiency aspect is assessed on the 
positive impact brought about in learning activities when applying digital games in the teaching process.

Among the ten types of learning skills formed by using seven typical types of digital games in the teaching process, the results from the survey (Table 4) showed that six types of learning skills were selected with the rate of over $50 \%$, such as Skills of thought and thinking practice (64.29\%); Hand and eye coordination (58.39\%); Decision making (58.32\%); Problem solving (55.34\%); Planning and strategy (52.08\%); Ingenuity training $(51.94 \%)$. These are all complex learning skills required to be applied and experienced by learners. In a digital game-based learning environment, challenges, competitions, and attractive elements of interactive multimedia can be integrated into learning contexts, so learning engagement is enhanced. Learners can persevere to gain more complex skills than in traditional learning environments. This result is similar to those found in Duplantis (2002) [40], Facer (2004) [41], Virvou (2005) [42], Papastergiou (2008), Wahidah (2020), Yamani (2021), which show that digital games can deliver complex, diverse learning abilities and goals. Thus, the feasibility of forming complex learning skills by using digital games opens many opportunities to apply digital games in the modern teaching process at HUST.

Concerning gender differences in assessing the effectiveness of digital games in teaching, boys play video games more frequently than girls. However, research suggests there are no differences between males and females in evaluating the effectiveness of digital games in HUST. This is similar to the studies of Papastergiou (2008), Ke \& Grabowski (2007) [43], which do not find gender difference when studying the effectiveness and motivation of learning under the impact of games.

Although IT students have many opportunities to be exposed to digital technology and digital games, a review of research on the effectiveness of teaching using digital games shows that both groups of students, IT and non-IT students have the same opinion. Thus, when applied in learning, digital games are evaluated to be equally effective regardless of whether the learners have experience in using digital technology in learning and research.

However, there is a difference in the perspective of teaching using digital games in two groups of students, the second-year students who study in general knowledge and the third-year students starting to study specialized subjects. Research shows a difference between them in emphasizing that teaching using digital games makes the learning process easy and exciting and teaching using digital games helps learners apply knowledge learned in games into real life. In particular, the group of students who are still studying general subjects has a higher appreciation of the effectiveness of teaching using digital games. This result can be explained that delivering in-depth knowledge and experience by using digital games is not enough; specialized students also need to combine with practical learning activities to form workmanship (not just pure virtual environments). The results of this study will guide future research to develop teaching solutions using digital games in blended learning environments, to promote the effectiveness of both real and virtual environments in higher education, especially the engineering education field, in later studies. 


\section{Acknowledgement}

This research was funded by the Ministry of Education and Training in Viet Nam under grant Number: CT2020.02.BKA.07

\section{$6 \quad$ References}

[1] $\mathrm{Vu}$ Hoang Lien (2020), Vietnam: The spotlight in developing education technology 4.0, The conference in Edu 4.0 (Hanoi 21/11/2020)

[2] Phung Thanh Chuong, Disadvantage of electronic games, Monthly News, Tuesday, 21-062011, 02:13 https://nhandan.com.vn/dien-dan-nhan-dan-hang-thang

[3] B.Y. White (1984), Designing computer games to help physics students understand newton's laws of motion. Cogn. Instr. 1(1), 69-108. https://doi.org/10.1207/s1532690xci0 $\underline{1014}$

[4] J. Lee, M. Trigueros, J. Tag€ ueña, R.A. Barrio, Spectrum: an educational computer game. Phys. Educ. 28(4), 215 (1993). https://doi.org/10.1088/0031-9120/28/4/004

[5] Marc Prensky (2001), Digital Game-Based Learning, McGraw-Hill

[6] John V. Dempsey, Linda L. Haynes, Barbara A. Lucassen, Maryann S. Casey (2002), Forty Simple Computer Games and What They Could Mean To Educators, SAGE Journals. https://doi.org/10.1177/1046878102332003

[7] Zyda, M. (2005). From visual simulation to virtual reality to games. Computer, 38(9), 2532. https://doi.org/10.1109/mc.2005.297

[8] N. Nazry, M. Nazrina, and D. M. Romano (2017), "Mood and learning in navigation-based serious games," Computers in Human Behavior, vol. 73, pp. 596-604, 2017. https://doi .org/10.1016/j.chb.2017.03.040

[9] A. A. Juan, B. Loch, T. Daradoumis, and S. Ventura (2017), "Games and simulation in higher education," International Journal of Educational Technology in Higher Education, vol. 14, no. 1, 2017. https://doi.org/10.1186/s41239-017-0075-9

[10] Sara I. de Freitas (2006), Using Games and Simulations for Supporting Learning, Learning Media and Technology. 31(4): 343-358, https://doi.org/10.1080/17439880601021967

[11] McGonigal, J. (2011). Reality is broken: Why games make us better and how they can change the world. New York, NY: Penguin

[12] Gilliam, M., Jagoda, P., Fabiyi, C., Lyman, P., Wilson, C., Hill, B., \& Bouris, A. (2017). Alternate reality games as an informal learning tool for generating STEM engagement among underrepresented youth: A qualitative evaluation of the source. Journal of Science Education and Technology, 26(3), 295-308. https://doi.org/10.1007/s10956-016-9679-4

[13] Barlow, N. (2006). Types of ARG. In IGDA Alternate Reality Games SIG (Ed.), 2006 Alternate Reality Games White Paper (pp.15-20). The International Game Developers Association.

[14] Dominik, M. (2008). The alternate reality game: Learning situated in the realities of the 21st century. In Proceedings of EdMedia: World Conference on Educational Media and Technology (pp. 2358-2363). Vienna, Austria: Association for the Advancement of Computing in Education (AACE). Retrieved from https://www.learntechlib.org/p/28694/

[15] Olbrish, K. (2011). The ABC's of ARGs: Alternate reality games for learning. eLearn Magazine. Retrieved from https://elearnmag.acm.org/archive.cfm?aid=2019544. https://doi.org/10.1145/2016016.2019544 
Van Grove, J. (2011). Gamification: How competition is reinventing business, marketing $\&$ everyday life. Retrieved from http://mashable.com/2011/07/28/gamification/\# jwRDwxY4Okqq

[16] Werbach, K., \& Hunter, D. (2012). For the win: How game thinking can revolutionize your business. Philadelphia, PA: Wharton Digital Press.

[17] Reeves, B., \& Read, J. L. (2009). Total engagement: How games and virtual worlds are changing the way people work and businesses compete. Boston, MA: Harvard Business Press.

[18] McGonigal, J. (2011). Reality is broken: Why games make us better and how they can change the world. New York, NY: Penguin.

[19] Zichermann, G., \& Linder, J. (2013). The gamification revolution: How leaders leverage game mechanics to crush the competition. New York, NY: McGraw Hill.

[20] Deterding, S., Dixon, D., Khaled, R., \& Nacke, L. (2011). From game design elements to gamefulness: Defining gamification. In Proceedings of the 15th international academic MindTrek conference: Envisioning future media environments (pp. 9-15). Tampere, Finland: ACM.

[21] Mohammed Abdulaziz Alsubhi et al (2020), A Conceptual Engagement Framework for Gamified E-Learning Platform Activities, iJET - Vol. 15, No. 22, 2020, https://doi.org/ 10.3991/ijet.v15i22.15443

[22] Nicola Whitton (2014), Digital Games and Learning: Research and Theory (Digital Games, Simulations, and Learning), Routledge Publish.

[23] Nguyen Xuan Lac (2017), Introduction to Modern Didactics and Instructional Technology, Vietnam Educational Publisher, ISBN: 978-604-0-10568-4

[24] Nguyen Thi Huong Giang, Implementation of Online Instructional Technology and HandsOn Skills Training, International Journal of Quality Assurance in Engineering and Technology Education (IJQAETE), Volume 3, Issue 2, p.65-76 April - June 2014, published: Quarterly in Print and Electronically, ISSN: 2155-496X; EISSN: 2155-4978; Published by IGI Global Publishing, Hershey, USA. https://doi.org/10.4018/ijqaete.2014040106

[25] James Paul Gee (2003), What Video Games Have to Teach Us About Learning and Literacy, New York: Palgrave/Macmillan. https://doi.org/10.5040/9781628927924.ch-013

[26] Ryan L. Schaaf (2015), Using Digital Games to Transform Teaching, Learning, and Assessment, Solution Tree Press

[27] Begoña Gros (2015), Integration of Digital Games in Learning and e- Learning Environments: Connecting Experiences and Context, Springer Science+Business Media Dordrecht

[28] Busch, C., Conrad, F., \& Steinicke, M. (2013). Digital games and the hero's journey in management workshops and tertiary education. The Electronic Journal of e-Learning, 11(1), 3-15.

[29] Nancy Sardone, Roberta Devlin-Scherer (2010), Teacher Candidate Responses to Digital Games, Journal of Research on Technology in Education, 42(4):409-425. https://doi.org/ $10.1080 / 15391523.2010 .10782558$

[30] Roslina Ibrahim, Hasiah Mohamed @ Omar, Rasimah Yusoff, Azizah Jaafar, Students Perceptions of Using Educational Games to Learn Introductory Programming, Computer and Information Science, https://doi.org/10.5539/cis.v4n1p205

[31] Marina Papastergiou, Digital Game-Based Learning in high school Computer Science education: Impact on educational effectiveness and student motivation, Computers \& Education Volume 52, Issue 1, January 2009, Pages 1-12, https://doi.org/10.1016/j.compedu. 2008.06.004

[32] Alper Cavus, Alfiya R. Masalimova, Vasil N. Farrakhov, Svetlana G. Kashina, Zhanna M. Sizova, Olga V. Popova (2020), Analysis of the Studies Published on Business Strategy 
Paper-Evaluating Feasibility and Effectiveness of Digital Game-Based Instructional Technology

Game and Learning Strategic Management in the Web of Science Database, iJET - Vol. 15, No. 23, 2020, https://doi.org/10.3991/ijet.v15i23.18789

[33] Thi Thanh Huyen Phuong (2020), Gamified Learning: Are Vietnamese EFL Learners Ready Yet?, iJET - Vol. 15, No. 24, 2020, https://doi.org/10.3991/ijet.v15i24.16667

[34] Abdul Rauf Baig, Amjad Alotaibi, Effect of Curriculum-Based Video Games on Students' Performance - An Experimental Study, iJET - Vol. 15, No. 22, 2020, https://doi.org/ 10.3991/ijet.v15i22.15541

[35] Nina Ikhwati Wahidah, Wiwin Rita Sari, Ike Festiana (2020), Game Based Learning: Design a Multimedia with DDD-E Model for Mathematics Education, iJET - Vol. 15, No. 21, 2020, https://doi.org/10.3991/ijet.v15i21.16353

[36] Ylva Backman, Viktor Gardelli, Peter Parnes (2021), Game Technologies to Assist Learning of Communication Skills in Dialogic Settings for Persons with Aphasia, iJET - Vol. 16, No. 03, 2021, https://doi.org/10.3991/ijet.v16i03.17889

[37] Hanaa Abdulraheem Yamani, (2021) A Conceptual Framework for Integrating Gamification in eLearning Systems Based on Instructional Design Model, iJET - Vol. 16, No. 04, 2021, https://doi.org/10.3991/ijet.v16i04.15693

[38] Glenn D. Israel. (1992). Determining Sample Size, University of Florida, IFAS Extension

[39] Duplantis, W., MacGregor, E., Klawe, M., \& Ng. M (2002) "Virtual family: An approach to introducing java programming, ACM SIGCSE Bulletin, 34(2), 40-43. https://doi.org/ $\underline{10.1145 / 543812.543827}$

[40] Facer, K., Joiner, R., Stanton, D., Reid, J., Hull, R., \& Kirk, D. (2004). Savannah: Mobile gaming and learning? Journal of Computer Assisted Learning, 20(6), 399-409. https://doi.org/10.1111/j.1365-2729.2004.00105.x

[41] Virvou, M., Katsionis, G., \& Manos, K. (2005). Combining software games with education: Evaluation of its educational effectiveness. Educational Technology and Society, $8(2), 54-65$.

[42] Ke, F. \& Grabowski, B. (2007), Game playing for maths learning: Cooperative or not? British Journal of Educational Technology, 38 (2), 249-259

\section{$7 \quad$ Authors}

Nguyen Thi Huong Giang is a major lecturer in the School of Engineering Pedagogy, Hanoi University of Science and Technology (HUST), No.1 Dai Co Viet Road, Hai Ba Trung District, Hanoi, Vietnam. She is also an Adjunct Associate Professor in the Facluty of Information Technology, Victorian Institute of Technology Pty Ltd, Melbourne, Australia. She studied Engineering and Master of Science in Electronices and Telecommunications at HUST and graduated from the Hanoi Education University with a Ph. D in Educational Sciences. Her research focus on Educational Technology, especially in eLearning and Emerging Technologies, Digital Transformation in Higher Education Institutions.

Le Huy Cuong is a computer scientist and the Director of BachKhoa Information Network Center, Hanoi University of Science and Technology (HUST), in Hanoi, Vietnam. He works also as a practical lecturer in the School of Information and Communication Technology at HUST. His research focus on Cyber Security, Digital Transformation in Higher Education and Digital Games Based Learning.

Article submitted 2021-05-08. Resubmitted 2021-06-13. Final acceptance 2021-06-14. Final version published as submitted by the authors. 